\title{
ON THE METAMORPHISM OF THE HAUKIVESI AREA
}

\author{
JORMA PAAVOLA
}

\begin{abstract}
PAAVOLA, JORMA 1976: On the metamorphism of the Haukivesi area. Bull. Geol. Soc. Finland 48, 1-3.

The distribution coefficient, $\mathrm{K}_{\mathrm{D}}=\frac{(\mathrm{Mg} / \mathrm{Fe}) \text { garnet }}{(\mathrm{Mg} / \mathrm{Fe}) \text { biotite }}$, has been calculated for 27 garnet - biotite pairs from the Haukivesi area. The results are compared with some $\mathrm{K}_{\mathrm{D}}$-values and some metamorphic temperatures determined recently in different parts of the world.

Jorma Paavola, Institute of Geology and Mineralogy, University of Turku, SF-20500 Turku 50, Finland.*

* Present address: Geological Survey of Finland, 70200 Kuopio 20, Finland
\end{abstract}

The Haukivesi area can be divided into three petrological and metamorphic zones (Gaál and Rauhamäki 1971): 1) the northern zone, characterized by a large area of veined gneisses (amphibolite facies) 2) the central zone, composed largely of hypersthene-bearing plutonic rocks, kinzigites and several types of migmatites (granulite facies) and 3) the southern zone, consisting mainly of metagraywackes with primary structures (amphibolite facies). This division is petrologically clear and natural. Metamorphically the central zone is more complicated than the marginal zones owing to the complicated deformation mechanism in the area and possible contact metamorphism.

To study to what extent the differences in the metamorphic grade are manifest in the distribution coefficient of $\mathrm{Mg}$ and $\mathrm{Fe}\left(\mathrm{K}_{\mathrm{D}}\right)$ between garnet and biotite, and in the chemi- cal composition of garnet, five localities were sampled six samples being taken from the northern zone and 21 from four different sites in the central zone.

According to Lyons and Morse (1970), who have collected $\mathrm{K}_{\mathrm{D}}$-values calculated by different authors, the average $\mathrm{K}_{\mathrm{D}}$-values are 0.130 for the metamorphic garnet-zone, 0.150 for the staurolite- and kyanite-zone and 0.274 for the sillimanite- and the sillimanite-orthoclase-zone rocks. Thus the $\mathrm{K}_{\mathrm{D}}$-value increases conspicuously with the increasing metamorphic grade.

The average $\mathrm{K}_{\mathrm{D}}$-values for the Haukivesi area, listed in Table 1 , are consistent with the values given by Lyons and Morse (1970).

Miyashiro (1953) observed a correlation between the increasing manganese content in garnet and the decreasing metamorphic 
Table 1. The average $\mathrm{K}_{\mathrm{D}}-$ values

\begin{tabular}{|c|c|c|c|}
\hline locality & $\mathrm{K}_{\text {Dav. }}$ & $\begin{array}{c}\text { num- } \\
\text { ber of } \\
\text { samp- } \\
\text { les }\end{array}$ & remarks \\
\hline $\begin{array}{l}\text { Tappuvirta } \\
\text { (northern } \\
\text { zone) }\end{array}$ & 0.158 & 6 & veined gneiss \\
\hline $\begin{array}{l}\text { Voinsalmi } \\
\text { (central } \\
\text { zone) }\end{array}$ & 0.275 & 5 & kinzigite \\
\hline $\begin{array}{l}\text { Voinsalmi } \\
\text { (breccia) } \\
\text { (central } \\
\text { zone) }\end{array}$ & 0.218 & 5 & $\begin{array}{l}\text { schollen and } \\
\text { agmatite }\end{array}$ \\
\hline $\begin{array}{l}\text { Vuorikiukas } \\
\text { (central } \\
\text { zone) }\end{array}$ & 0.236 & 6 & $\begin{array}{l}\text { partly Ca- } \\
\text { rich; veined }\end{array}$ \\
\hline $\begin{array}{l}\text { Poronsalmi } \\
\text { (central } \\
\text { zone) }\end{array}$ & 0.214 & 5 & $\begin{array}{l}\text { contact meta- } \\
\text { morphism evi- } \\
\text { dent }\end{array}$ \\
\hline
\end{tabular}

grade. The same seems to be true in the present study (Fig. 1), especially when $\mathrm{K}_{\mathrm{D}}<$ 0.20 .

The low metamorphic garnets are marked by their Mn content, whereas in the high metamorphic garnets it is the increase in $\mathrm{Mg}$ that is most striking. The $\mathrm{Fe}-\mathrm{Mg}-\mathrm{Mn}$ com-

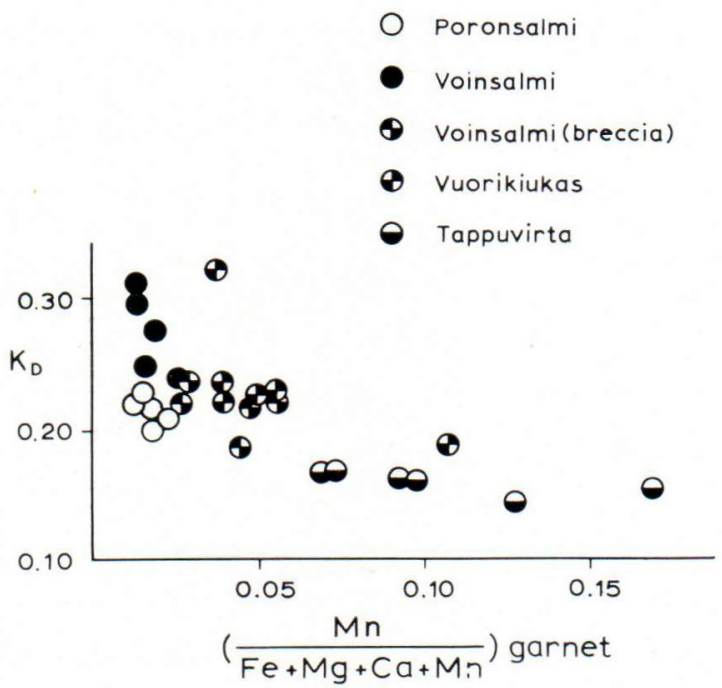

Fig. 1. The correlation between $\mathrm{K}_{\mathrm{D}}$ and the manganese content of garnet.

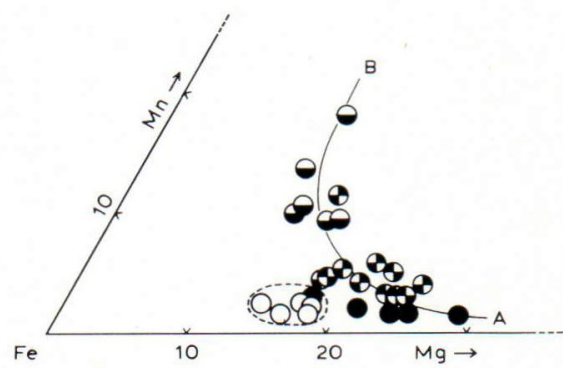

Fig. 2. The chemical composition of garnet. Triangular diagram Fe-Mg-Mn.

position of garnet seems to follow approximately the curved line $\mathrm{AB}$ illustrated in Fig. 2. In composition the garnets coexisting with cordierite form a separate group in the diagram (encircled by a broken line in Fig. 2).

Perchuk (1970) has worked out metamorphic temperature diagrams as a function of

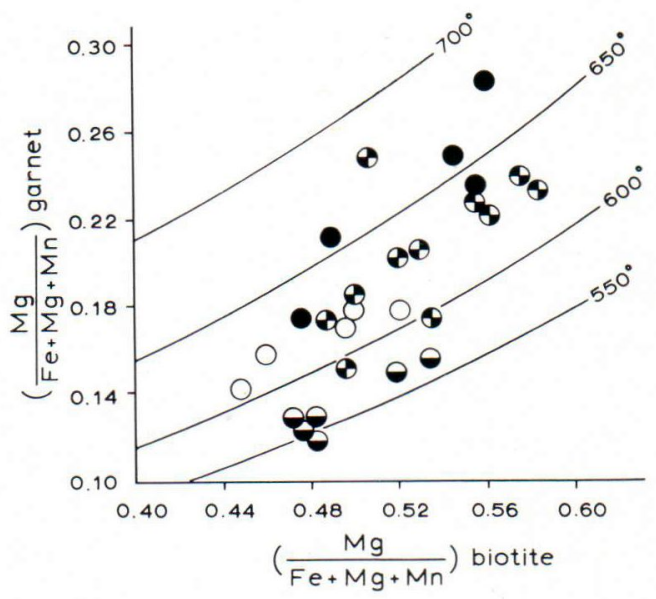

Fig. 3. The correlation between $\left(\frac{\mathrm{Mg}}{\mathrm{Fe}+\mathrm{Mg}+\mathrm{Mn}}\right)$ garnet and $\left(\frac{\mathrm{Mg}}{\mathrm{Fe}+\mathrm{Mg}+\mathrm{Mn}}\right)$ biotite. Isotherms fixed by Perchuk (1970). 
$\mathrm{Fe}-\mathrm{Mg}-\mathrm{Mn}$ distribution between garnet and biotite. He does not consider pressure to be very important in this respect and he maintains that the distribution is mainly dependent on the temperature. Fig. 3 shows the metamorphic temperatures of the Haukivesi samples according to Perchuk's diagram. The average temperature differences between the districts compared are conspicuous.
According to the mineral parageneses observed and to the $\mathrm{K}_{\mathrm{D}}$ - values and temperatures given above, the northern zone of the Haukivesi area represents low amphibolite facies conditions. The central zone is much more variable and can be considered to belong partly to the high amphibolite facies and partly to the granulite facies. Contact metamorphic effects are also in evidence.

\section{REFERENCES}

Gaál, G. and Rauhamäki, E. (1971) Petrological and structural analysis of the Haukivesi area between Varkaus and Savonlinna, Finland. Bull. Geol. Soc. Finland 43 (2): 265-337.

Lyons, J. B. and Morse, S. A. (1970) $\mathrm{Mg} / \mathrm{Fe}$ partitioning in garnet and biotite from some granitic, pelitic and calcic rocks. Am. Miner. 55: $231-244$.
Miyashiro, A. (1953) Calcium-poor garnet in relation to metamorphism. Geochim. Cosmochim. Acta 4: 179-208.

Perchuk, L. L. (1970) Selected articles; Equilibrium of biotite with garnet in metamorphic rocks. Geochem. Int. 7: 157-177.

Manuscript received, April 2, 1975. 